\title{
A Polyphasic Reassessment of the Genus Aneurinibacillus, Reclassification of Bacillus thermoaerophilus (Meier-Stauffer et al. 1996) as Aneurinibacillus thermoaerophilus comb. nov., and Emended Descriptions of $A$. aneurinilyticus corrig., $A$. migulanus, and $A$. thermoaerophilus
}

\author{
M. HEYNDRICKX, ${ }^{1}$ L. LEBBE,${ }^{1}$ M. VANCANNEYT, ${ }^{1}$ K. KERSTERS, ${ }^{1}$ P. DE VOS, ${ }^{1 *}$ N. A. LOGAN, ${ }^{2}$ \\ G. FORSYTH, ${ }^{2}$ S. NAZLI, ${ }^{2}$ N. ALI, ${ }^{3}$ AND R. C. W. BERKELEY ${ }^{3}$ \\ Laboratorium voor Microbiologie, Universiteit Gent, B-9000 Ghent, Belgium, ${ }^{1}$ and Department of Biological Sciences, \\ Glasgow Caledonian University, Glasgow G4 OBA, ${ }^{2}$ and Department of Pathology and Microbiology, \\ School of Medical Sciences, University of Bristol, Bristol BS8 $1 T D,{ }^{3}$ United Kingdom
}

\begin{abstract}
Fifty-three strains representing 25 species of aerobic endospore-forming bacteria, of which 11 (37 strains) belong to the genera Aneurinibacillus and Brevibacillus (Bacillus rRNA group 4 of Ash et al. [Lett. Appl. Microbiol. 13:202-206, 1991]), were characterized genotypically by amplified ribosomal DNA restriction analysis (ARDRA) and/or phenotypically by fatty acid methyl ester analysis, sodium dodecylsulfate-polyacrylamide gel electrophoresis of whole-cell proteins, pyrolysis mass spectrometry, 99 API Biotype 100 assimilation tests, and 16 other routine phenotypic tests. ARDRA revealed that Aneurinibacillus aneurinilyticus, Aneurinibacillus migulanus, and Bacillus thermoaerophilus formed a cluster quite separate from Brevibacillus species, supporting the distinction of both genera and the transfer of $B$. thermoaerophilus to the genus Aneurinibacillus. Two of the species, $A$. aneurinilyticus (the type species) and $A$. migulanus, are phenotypically and genotypically quite similar but can be distinguished from each other by several phenotypic characters. Phenotypic differentiation at the generic level is also described.
\end{abstract}

Bacillus aneurinolyticus [sic] was described by Aoyama (1) as a thiamine-decomposing organism from human feces but was omitted from the Approved Lists of Bacterial Names (25) because of the paucity of representative strains. (We will use the corrected species epithet aneurinilyticus according to Appendix 9B of the International Code of Nomenclature of Bacteria [1990].) Phenotypically, this organism is known to resemble Bacillus brevis and related taxa (3), and studies on the $16 \mathrm{~S}$ rRNA sequences of the type strains of these two species suggest that $B$. aneurinilyticus represents a distinct evolutionary line close to that of $B$. brevis (2) or that it diverged early from the $B$. brevis line $(5,6)$.

The taxonomy of $B$. brevis has been modified by assigning $B$. brevis strains to a number of new species, such as Bacillus agri and Bacillus centrosporus (17); Bacillus migulanus, Bacillus choshinensis, Bacillus parabrevis, and Bacillus galactophilus (27); and Bacillus reuszeri, Bacillus formosus, and Bacillus borstelensis (22). Also, the name $B$. aneurinilyticus has been revived (20), and that of $B$. galactophilus has been recognized to be a synonym of B. agri (21). The thermophilic species Bacillus thermoaerophilus has been described to include sugar beet isolates and $B$. brevis ATCC 12990 (16).

Recently, two new genera were created on the basis of a $16 \mathrm{~S}$ rDNA gene sequence analysis (of the type strains only) to accommodate the above-mentioned and allied species; the genus Aneurinibacillus contains $A$. aneurinilyticus and $A$. migula$n u s$, while the genus Brevibacillus contains Brevibacillus brevis and the species derived from it (see above), Brevibacillus lat-

* Corresponding author. Mailing address: Laboratorium voor Microbiologie, Vakgroep BFM WE10V, Universiteit Gent, K. L. Ledeganckstraat 35, B-9000 Ghent, Belgium. Phone: 32 (0)9 2645110 . Fax: 32 (0)9 264 5346. E-mail: Paul.Devos@rug.ac.be. erosporus and Brevibacillus thermoruber (23). B. thermoaerophilus was not included in the latter study.

As a continuation of the collaborative taxonomic study by some members of the International Committee on Systematic Bacteriology Subcommittee on the Taxonomy of the Genus Bacillus and Related Organisms (13), a polyphasic study of the new genus Aneurinibacillus that also included representative strains of the new genus Brevibacillus as well as $B$. thermoaerophilus and some other Bacillus species was undertaken in order to clarify the positions of the strains at different taxonomic levels and to identify phenotypic characters allowing distinction among them.

\section{MATERIALS AND METHODS}

Strains and media. The designations of the strains, their origins, and the different methods applied to each are shown in Table 1 . Unless otherwise stated, strains were grown on nutrient agar with $1 \%$ (wt/vol) glucose ( $\mathrm{pH} 7.4)$ (NAG) a $30^{\circ} \mathrm{C}$ for 24 to $48 \mathrm{~h}$, except for $B$. thermoaerophilus, which was grown at $55^{\circ} \mathrm{C}$. The strains were checked for purity by plating and phase-contrast microscopic examination and were maintained both as lyophilized cultures and as sporulated cultures on NAG slopes containing $5 \mathrm{mg}$ of $\mathrm{MnSO}_{4} \cdot 4 \mathrm{H}_{2} \mathrm{O}$ per liter (to enhance sporulation). Slopes were incubated for $48 \mathrm{~h}$ or longer until spores could be observed by microscopy, and they were then stored at $4^{\circ} \mathrm{C}$

DNA preparation. For amplified ribosomal DNA restriction analysis (ARDRA), total genomic DNA was purified by a slight modification of the method of Pitcher et al. (18), as described previously (11). The DNA of $A$ aneurinilyticus LMG $15531^{\mathrm{T}}$ and $A$. migulanus $\mathrm{LMG} 15427^{\mathrm{T}}$ for DNA-DNA binding experiments (see below) was prepared from 6 to $14 \mathrm{~g}$ (wet weight) of cells grown in Roux flasks containing $130 \mathrm{ml}$ of Trypticase soy agar (TSA). For DNA preparation, the method of Pitcher et al. (18) was modified as follows. Ten milliliters of cell suspension in TE buffer (10 mM Tris-HCl, $1 \mathrm{mM}$ EDTA; $\mathrm{pH}$ 8.0 ) was treated with $250 \mathrm{mg}$ of lysozyme at $37^{\circ} \mathrm{C}$ for $0.5 \mathrm{~h}$. Then TE buffer was added to bring the volume up to $50 \mathrm{ml}$, and the cells were lysed by adding $20 \mathrm{ml}$ of guanidium-EDTA-Sarkosyl reagent (see reference 18). Lysed cells were vigorously shaken in $1 \mathrm{M} \mathrm{NaCl}$ and then treated with ammonium acetate at a final concentration of $2.2 \mathrm{M}$. After removal of proteins and cell debris by a double chloroform extraction (involving gentle shaking for $20 \mathrm{~min}$ ) and centrifugation for $40 \mathrm{~min}$ at $23,500 \times \mathrm{g}$, the DNA was precipitated from the aqueous phase with 0.54 volumes of isopropanol, spooled on a glass rod, and dissolved in $0.1 \times \mathrm{SSC}$ 
TABLE 1. Designations and sources of Aneurinibacillus, Brevibacillus, and Bacillus strains used, and an overview of the different characterization methods applied to them

\begin{tabular}{|c|c|c|c|c|c|c|c|c|}
\hline \multirow{2}{*}{ Strain $^{a}$} & \multirow{2}{*}{ LMG number } & \multirow{2}{*}{ Other designation $(\mathrm{s})^{b}$} & \multirow{2}{*}{ Source $^{b}$} & \multicolumn{5}{|c|}{ Method(s) applied } \\
\hline & & & & ARDRA & API & PAGE & FAME & Py-MS \\
\hline Aneurinibacillus aneurinilyticus & LMG $15531^{\mathrm{T}}$ & B0205, ATCC $12856^{\mathrm{T}}, \mathrm{JCM} 9024^{\mathrm{T}}$ & Gordon & + & + & + & + & + \\
\hline A. aneurinilyticus & LMG 12387 & B0202, ATCC 11376, NRS 1443 & Gordon & + & + & + & + & \\
\hline A. aneurinilyticus & LMG 15532 & B0206, NRRL NRS-1448 & Gordon & + & + & + & + & + \\
\hline A. aneurinilyticus & LMG 15533 & B0207, NRRL NRS-1449 & Gordon & + & + & + & + & + \\
\hline A. aneurinilyticus & LMG 15534 & B0208, NRRL NRS-1450 & Gordon & + & + & + & + & + \\
\hline A. aneurinilyticus & LMG 15535 & B0209, NRRL NRS-1451 & Gordon & + & + & + & + & + \\
\hline A. aneurinilyticus & LMG 15967 & B4045, ATCC 11376, JCM 9023 & ATCC & + & + & + & + & + \\
\hline A. aneurinilyticus & LMG 16001 & DSM 5562 & DSM & + & + & + & + & + \\
\hline A. aneurinilyticus & LMG 16008 & B4027, IFO 3115, JCM 7539 & IFO & + & + & + & + & + \\
\hline A. aneurinilyticus & LMG 17160 & NCIMB 10059 & NCIMB & + & + & + & + & \\
\hline A. aneurinilyticus & LMG 17161 & NCIMB 10060 & NCIMB & + & + & + & + & \\
\hline A. aneurinilyticus & LMG 17162 & NCIMB 10061 & NCIMB & + & + & + & + & \\
\hline A. [aneurinilyticus] & LMG 17164 & NCIMB 10057 & NCIMB & + & + & + & + & \\
\hline A. migulanus & LMG $15427^{\mathrm{T}}$ & B0270, NCTC $7096^{\mathrm{T}}$, ATCC $9999^{\mathrm{T}}$ & NCTC & + & + & + & + & + \\
\hline A. migulanus & LMG 16098 & B4036, NRRL NRS-606 & Nakamura & + & + & + & + & + \\
\hline Bacillus amyloliquefaciens & LMG $9814^{\mathrm{T}}$ & DSM $3034^{\mathrm{T}}$ & DSM & + & & & & \\
\hline B. azotoformans & LMG $9581^{\mathrm{T}}$ & CCM $2849^{\mathrm{T}}$, АТCC $29788^{\mathrm{T}}$ & $\mathrm{CCM}$ & + & & & & \\
\hline B. badius & LMG $7122^{\mathrm{T}}$ & DSM $23^{\mathrm{T}}$ & DSM & + & + & + & + & + \\
\hline B. badius & LMG 12332 & B0201, NRS 1407 & Gordon & + & + & + & + & \\
\hline B. cereus & LMG $6923^{\mathrm{T}}$ & DSM $31^{\mathrm{T}}$ & DSM & + & & & & \\
\hline B. circulans & LMG $13261^{\mathrm{T}}$ & $\mathrm{B} 0004^{\mathrm{T}}$, DSM $11^{\mathrm{T}}$ & DSM & + & & & & \\
\hline B. firmus & LMG $7125^{\mathrm{T}}$ & DSM $12^{\mathrm{T}}$ & DSM & + & & & & \\
\hline B. licheniformis & LMG $6933^{\mathrm{T}}$ & DSM $13^{\mathrm{T}}$ & DSM & + & & & & \\
\hline B. megaterium & LMG $7127^{\mathrm{T}}$ & DSM $32^{\mathrm{T}}$ & DSM & + & & & & \\
\hline B. simplex & LMG $11160^{\mathrm{r}}$ & DSM $1321^{\mathrm{T}}$ & DSM & + & & & & \\
\hline B. sphaericus & LMG $7134^{\mathrm{T}}$ & $\mathrm{B} 0012^{\mathrm{T}}$, DSM $28^{\mathrm{T}}$ & DSM & + & & & & \\
\hline B. subtilis & LMG $7135^{\mathrm{T}}$ & DSM $10^{\mathrm{T}}$ & DSM & + & & & & \\
\hline B. thermoaerophilus & LMG $17165^{\mathrm{T}}$ & DSM $10154^{\mathrm{T}}$ & DSM & + & + & + & + & \\
\hline B. thermoaerophilus & LMG 17166 & DSM 10155 & DSM & + & + & + & + & \\
\hline B. thuringiensis & LMG $7138^{\mathrm{T}}$ & DSM $2046^{\mathrm{T}}$ & DSM & + & & & & \\
\hline Brevibacillus agri & LMG $15103^{\mathrm{T}}$ & CCUG $31345^{\mathrm{T}}$, NRRL NRS- $1219^{\mathrm{T}}$ & CCUG & + & + & + & + & + \\
\hline B. agri & LMG 15102 & CCUG 31344, NRRL B-1157 & CCUG & + & & + & + & \\
\hline B. agri & LMG 15592 & B4001, NRRL B-1157 & Nakamura & & + & & & + \\
\hline B. borstelensis & LMG $16009^{\mathrm{T}}$ & $\mathrm{B} 4029^{\mathrm{T}}$, IFO $15714^{\mathrm{T}}$ & IFO & + & + & + & + & + \\
\hline B. borstelensis & LMG 15599 & B4009, NRRL NRS-1373 & Nakamura & + & + & + & + & + \\
\hline B. brevis & LMG $16703^{\mathrm{T}}$ & ATCC $8246^{\mathrm{T}}$ & ATCC & + & + & + & + & + \\
\hline [B. brevis] & LMG 12423 & B0117, Gibson strain 442 & Gibson & + & + & + & + & + \\
\hline B. [brevis] & LMG 15431 & B0629, Wellcome 2934 & Goodfellow & + & + & & + & + \\
\hline B. brevis & LMG 17054 & ATCC 11031 & ATCC & + & + & & + & \\
\hline B. brevis & LMG 17055 & ATCC 35690 & ATCC & & + & & & \\
\hline B. centrosporus & LMG $15106^{\mathrm{T}}$ & CCUG $31347^{\mathrm{T}}$, NRRL NRS- $664^{\mathrm{T}}$ & CCUG & + & + & + & + & + \\
\hline B. centrosporus & LMG 15602 & B4015, NRRL NRS-632 & Nakamura & + & + & + & + & + \\
\hline B. choshinensis & LMG $15968^{\mathrm{T}}$ & B $4046^{\mathrm{T}}$, ATCC $51359^{\mathrm{T}}, \mathrm{JCM} 8505^{\mathrm{T}}$ & ATCC & + & + & + & + & + \\
\hline B. choshinensis & LMG 16096 & B4033, NRRL NRS-378 & Nakamura & + & + & + & + & + \\
\hline B. formosus & LMG $16010^{\mathrm{T}}$ & $\mathrm{B} 4039^{\mathrm{T}}$, NRRL NRS- $863^{\mathrm{T}}$ & Nakamura & + & + & + & + & + \\
\hline B. formosus & LMG 16101 & B4040, NRRL NRS-910 & Nakamura & + & + & + & + & \\
\hline B. laterosporus & LMG $16000^{\mathrm{T}}$ & $\mathrm{B} 4035^{\mathrm{T}}, \mathrm{DSM} 25^{\mathrm{T}}, \mathrm{ATCC} 64^{\mathrm{T}}$ & DSM & + & + & + & + & + \\
\hline B. laterosporus & LMG 15436 & B0116, Gibson 1066 "B. orpheus" & Gibson & + & + & + & + & \\
\hline B. parabrevis & LMG $15971^{\mathrm{T}}$ & $\mathrm{B} 4047^{\mathrm{T}}$, ATCC $10027^{\mathrm{T}}$ & ATCC & + & + & + & + & + \\
\hline B. parabrevis & LMG 15428 & B0271, Gibson 108, NCTC 7577 & NCTC & + & + & + & + & + \\
\hline B. reuszeri & LMG $16012^{\mathrm{T}}$ & B4042 ${ }^{\mathrm{T}}$, NRRL NRS-1206 ${ }^{\mathrm{T}}$ & Nakamura & + & + & + & + & + \\
\hline B. reuszeri & LMG 16105 & B4043, NRRL NRS-1207 & Nakamura & + & + & + & + & + \\
\hline Sporosarcina ureae & LMG $17366^{\mathrm{T}}$ & $\mathrm{B} 0819^{\mathrm{T}}, \mathrm{CCM} 684^{\mathrm{T}}$ & CCM & + & & & & \\
\hline
\end{tabular}

${ }^{a}$ Names shown in brackets have uncertain taxonomic species or genus statuses; e.g., $A$. aneurinilyticus LMG 17164 belongs to $A$. migulanus according to Shida et al. (20). ${ }^{b}$ Abbreviations: ATCC, American Type Culture Collection, Rockville, Md.; B, N. A. Logan Bacillus collection, Glasgow Caledonian University, Glasgow, United Kingdom; CCM, Czech Collection of Microorganisms, Masaryk University, Brno, Czech Republic; CCUG, Culture Collection of the University of Göteborg, Göteborg, Sweden; DSM, Deutsche Sammlung von Mikroorganismen und Zellkulturen, Braunschweig, Germany; Gibson, T. Gibson collection, held at Glasgow Caledonian University, Glasgow, United Kingdom; Goodfellow, M. Goodfellow, University of Newcastle, Newcastle upon Tyne, United Kingdom; Gordon, R. E. Gordon, Rutgers University, New Brunswick, N.J.; IFO, Institute for Fermentation Osaka collection, Osaka, Japan; JCM, Japan Collection of Microorganisms, Institute of Physical and Chemical Research, Saitama, Japan; LMG, Laboratorium voor Microbiologie collection, Universiteit Gent, Ghent, Belgium; Nakamura, L. K. Nakamura, U.S. Department of Agriculture, Peoria, Ill.; NCIMB, National Collection of Industrial and Marine Bacteria, Aberdeen, United Kingdom; NCTC, National Collection of Type Cultures, Central Public Health Laboratory, London, United Kingdom; NRRL, Northern Regional Research Laboratory collection, Peoria, Ill.; Wellcome, Wellcome Research Laboratories, Beckenham, Kent, United Kingdom. 
(10× $\mathrm{SSC}$ is $1.5 \mathrm{M} \mathrm{NaCl}$ plus $0.15 \mathrm{M}$ trisodium citrate, $\mathrm{pH} 7.0$ ). The dissolved DNA was treated with RNase A (final concentration, $100 \mu \mathrm{g} / \mathrm{ml}$ in $1 \times \mathrm{SSC}$ ) for $1 \mathrm{~h}$ at $37^{\circ} \mathrm{C}$. The RNase was removed by a single chloroform extraction and centrifugation (as described above), and the DNA was precipitated with 0.54 volumes of isopropanol and spooled on a glass rod. After consecutive washing steps in 70,80, 90, and $95 \%$ ethanol and short periods of air drying, the DNA was dissolved in a small volume of $0.1 \times \mathrm{SSC}$ containing a few drops of chloroform and stored at $-80^{\circ} \mathrm{C}$

All DNA preparations were visually inspected for DNA integrity by $1 \%$ (wt/ vol) agarose gel electrophoresis and were measured spectrophotometrically at 234,260 , and $280 \mathrm{~nm}$ to check the DNA purity as indicated by an optical density ratio, $\mathrm{OD}_{260} / \mathrm{OD}_{260}$, of between 0.45 and 0.70 and an $\mathrm{OD}_{260} / \mathrm{OD}_{280}$ ratio of between 1.7 and 2.0 .

DNA-DNA binding. DNA-DNA binding reactions were determined spectrophotometrically by the initial renaturation method of De Ley et al. (4), and the results were expressed as percentages as described by Willems et al. (31).

ARDRA. Enzymatically amplified $16 \mathrm{~S}$ ribosomal DNA (rDNA) was obtained from each strain by PCR and analyzed by digestion with five restriction enzymes (HaeIII, DpnII, RsaI, BfaI, and Tru9I) as described previously (11). The restriction patterns for each strain were combined, and the combined normalized patterns were subjected to numerical analysis with the Gelcompar 4.0 software (Applied Maths, Kortrijk, Belgium), using the Dice coefficient and the unweighted pair group method using arithmetic averages (UPGMA) clustering algorithm.

Gas chromatographic analysis of fatty acid methyl esters (FAME). Cells were grown on TSA at $28^{\circ} \mathrm{C}$ for $24 \mathrm{~h}$ as recommended by the manufacturers of the Microbial Identification System (MIS) (Microbial ID, Inc., Newark, Del.), except for $B$. thermoaerophilus, which was grown at $55^{\circ} \mathrm{C}$. Methods for fatty acid extraction, methyl ester preparation, and methyl ester separation by gas chromatography were described previously (29). The fatty acid methyl ester profiles were identified and clustered by using the MIS software (version 4.0).

Sodium dodecyl sulfate (SDS)-polyacrylamide gel electrophoresis (PAGE) of whole-cell proteins. Cells for SDS-PAGE were obtained after $24 \mathrm{~h}$ of growth on NAG at $30^{\circ} \mathrm{C}$, except for those of $B$. thermoaerophilus, which was grown at 30 and $55^{\circ} \mathrm{C}$. Methods for preparation and electrophoresis of SDS protein extracts and for UPGMA cluster analysis of the protein profiles were described previously $(19,30)$

Phenotypic characterization and numerical analysis. As the methods of Gordon et al. (8) and Logan and Berkeley (15) are unable to separate A. aneurinilyticus, $A$. migulanus, members of the genus Brevibacillus, and Bacillus badius satisfactorily because most of these species are unreactive in most of the tests, the organisms were characterized by using carbon source assimilation tests in the API Biotype 100 system (bioMérieux, Marcy l'Etoile, France). Strains were cultivated for 24 to $48 \mathrm{~h}$ on TSA, cells were harvested in sterile distilled water, and suspensions were prepared in Biotype Medium 2 (containing 31 growth factors) to turbidities equivalent to the no. $3 \mathrm{McF}$ arland standard and then inoculated into test strips for the API Biotype 100 system, which comprises 99 carbon source assimilation tests and one negative control. Assimilation reactions at $30^{\circ} \mathrm{C}\left(55^{\circ} \mathrm{C}\right.$ for strains of $B$. thermoaerophilus) were followed for 4 days ( 2 days for strains of $B$. thermoaerophilus) and scored 4,3,2, 1 (for positive results after $1,2,3$, and 4 days, respectively), or 0 (for negative reactions). Strains were grown overnight at $30^{\circ} \mathrm{C}\left(55^{\circ} \mathrm{C}\right.$ for strains of $B$. thermoaerophilus $)$ in nutrient broth for inoculation of media for four other phenotypic observations: hydrolysis of casein and gelatin and growth at 20 and $55^{\circ} \mathrm{C}$ were tested by the methods of Gordon et al. (8) and scored as 1 (positive) or 0 (negative). Twelve characteristics of vegetative-cell and sporangial morphologies were observed as described by Logan and Berkeley (15) and scored as 1 (positive) or 0 (negative). Redundant tests (i.e., positive or negative for all strains) were excluded, and the data were subjected to numerical taxonomic analysis with the GENSTAT 5 program. Similarities were calculated by using the general similarity coefficient of Gower $\left(S_{G}\right)$ (9). Negative matches in the API Biotype 100 tests were excluded, and test ranges were set higher than those observed to compensate for bias attributable to negative results from weakly reacting strains (14). Results were examined by UPGMA cluster analysis and expressed at $2.5 \%$ intervals.

Pyrolysis mass spectrometry (Py-MS). Each strain was grown on duplicate plates of nutrient agar for 24 to $48 \mathrm{~h}$, and duplicate samples were taken from each plate for analysis. Preparation and Py-MS of the bacterial samples and normalization, cluster analysis based on the $S_{G}$ coefficient, and canonical variates analysis of the data with the GENSTAT statistical software were performed as described previously $(7,10)$

\section{RESULTS AND DISCUSSION}

A polyphasic study of the genus Aneurinibacillus. In a numerical analysis of combined ARDRA patterns (Fig. 1), the two species of Aneurinibacillus, $A$. aneurinilyticus (13 strains) and $A$. migulanus ( 2 authentic strains and an erroneously identified Brevibacillus brevis strain, LMG 12423), were recovered in one cluster at a similarity level of $91 \% .16 \mathrm{~S}$ rDNA sequence similarities of $98.6 \%(23)$ and $99.7 \%$ (16), respectively, were reported for the type strains of these two species. In the ARDRA dendrogram, the two strains of the thermophilic species $B$. thermoaerophilus were the nearest neighbors of this cluster, with a similarity level of $68 \%$, confirming again the results of 16S rDNA sequence comparison of Meier-Stauffer et al. (16) based on the type strains only. The representatives of the genera Brevibacillus, Paenibacillus, and Bacillus rRNA groups 1 and 2 were further removed; Brevibacillus strains showed a somewhat higher relationship of $50 \%$ to Aneurinibacillus strains and $B$. thermoaerophilus (Fig. 1). With ARDRA, a reliable allocation of strains to the different genera split off from the genus Bacillus or to the remaining Bacillus rRNA groups can thus be accomplished. Furthermore, our data indicate that $B$. thermoaerophilus shows a closer relationship to the genus Aneurinibacillus than to all other genera and Bacillus rRNA groups investigated.

In the FAME analysis, $A$. aneurinilyticus, $A$. migulanus, and, surprisingly, $B$. badius were shown to have quite similar fatty acid profiles, while that of $B$. thermoaerophilus was different The latter result can be at least partly explained by the difference in cultivation temperature; $B$. thermoaerophilus strains could not be grown at the normal mesophilic temperature of $28^{\circ} \mathrm{C}$ as recommended by the manufacturers of the MIS identification system and were cultivated at $55^{\circ} \mathrm{C}$. Indeed, a shift in fatty acid composition toward longer-chain fatty acids and lower ratios of unsaturated fatty acids to saturated fatty acids for the thermophylic strains compared to the mesophilic strains (as can be deduced from Table 2) have been mentioned as being linked with a higher growth temperature (26).

The remarkable high degree of similarity between the fatty acid profile of $B$. badius and those of the mesophilic strains of Aneurinibacillus, however, remains unexplained. Nevertheless, $16 \mathrm{~S}$ rDNA sequence comparisons $(2,5)$ and ARDRA (this paper) clearly locate $B$. badius in, or at least at the periphery of, the main Bacillus rRNA group, group 1 (2). Finally, all taxa can be distinguished (Table 2 ) by qualitative and quantitative differences in fatty acid composition. It should be noted here that $A$. [aneurinilyticus] LMG 17164 (see footnote $a$ in Table 1) showed a typical $A$. aneurinilyticus fatty acid profile yet behaved as an outlier of the Aneurinibacillus- $B$. badius group in other phenotypic analyses (see below). Hence, it was assumed that this strain was misidentified at the species level (20), and its fatty acid profile was not included when the mean fatty acid profile of $A$. migulanus was calculated (Table 2).

In the analysis of API Biotype 100 and other phenotypic characters, $A$. migulanus, $B$. thermoaerophilus, and $B$. badius strains, as well as most strains of $A$. aneurinilyticus, were recovered in separate but closely related clusters which merged at $57.5 \% S_{G}$ and then joined with the Brevibacillus cluster at $42.5 \% S_{G}$ (Fig. 2). Most strains of the genera Aneurinibacillus, Bacillus, and Brevibacillus have been recovered in single-species clusters, but the separations of several species are not distinct; this is due to the existence of considerable withinspecies variation in the API Biotype 100 tests. Although the separation of the main $A$. aneurinilyticus cluster from the clusters of $A$. migulanus, $B$. thermoaerophilus, and $B$. badius is modest (largely due to the two atypical strains LMG 17160 and LMG 17162), several phenotypic characters can be found to separate these species from each other and from Brevibacillus species on the basis of the strains examined in this study (Table 3). Strain LMG 12423, which was received as Brevibacillus brevis, showed a phenotypic profile characteristic of $A$. migulanus and was recovered in the $A$. migulanus cluster (Fig. 2); we therefore reclassify it here as a strain of $A$. migulanus.

Two other strains received as Aneurinibacillus species were not recovered in their respective clusters, and the characters of 


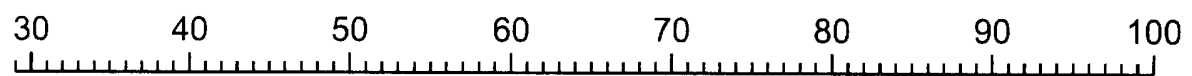

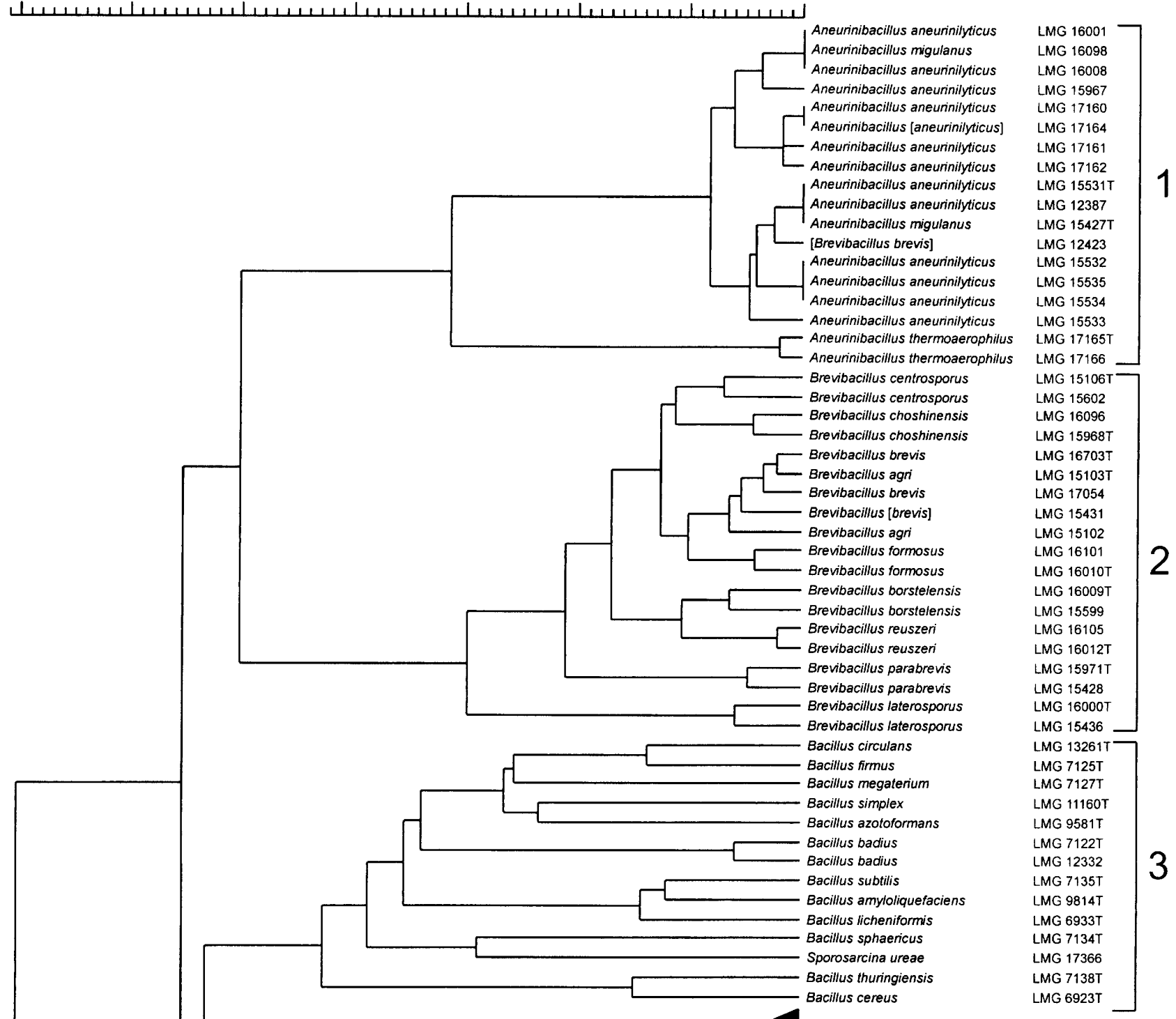



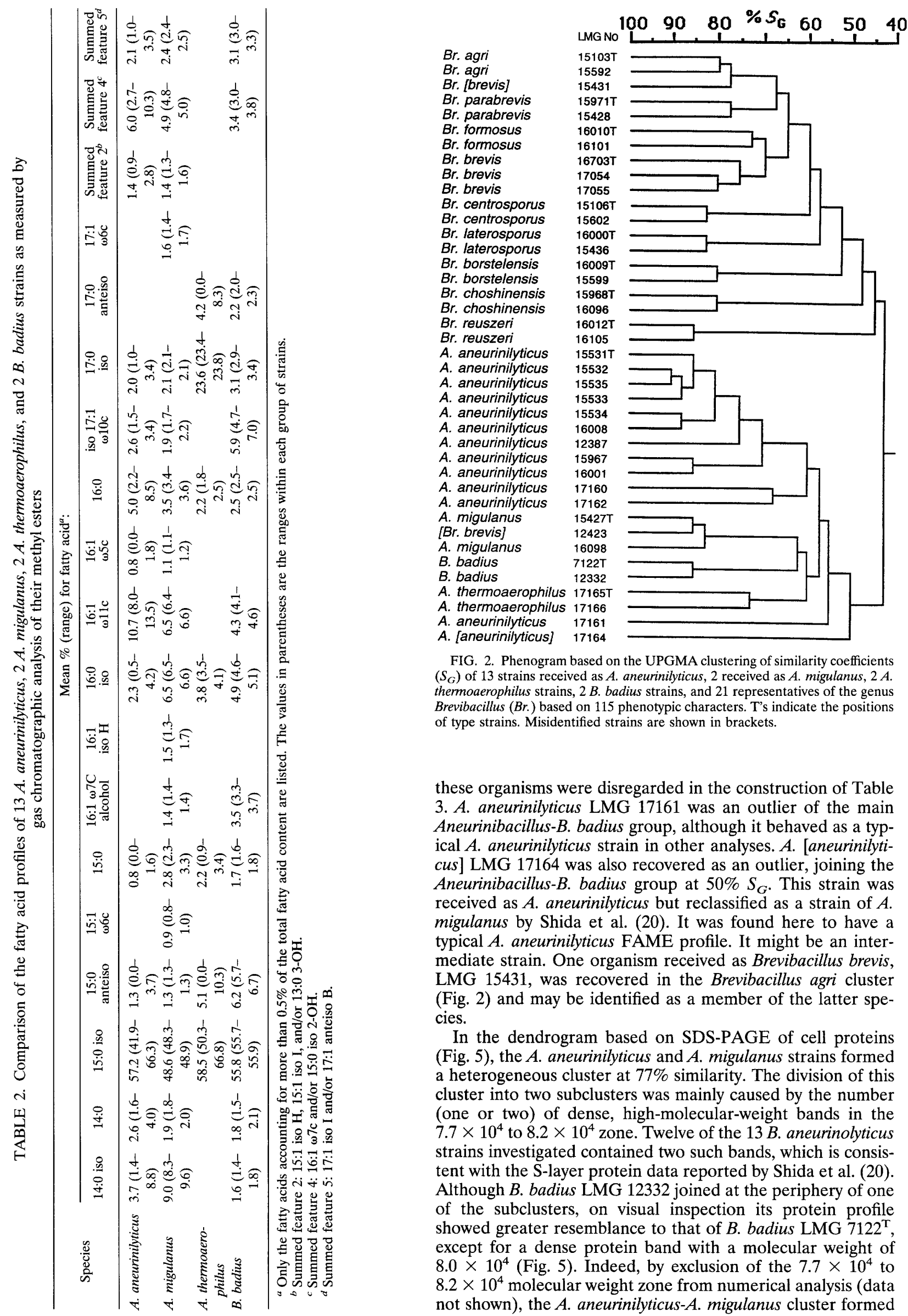

FIG. 2. Phenogram based on the UPGMA clustering of similarity coefficients $\left(S_{G}\right)$ of 13 strains received as $A$. aneurinilyticus, 2 received as $A$. migulanus, $2 A$. thermoaerophilus strains, $2 B$. badius strains, and 21 representatives of the genus Brevibacillus ( $B r$.) based on 115 phenotypic characters. T's indicate the positions of type strains. Misidentified strains are shown in brackets.

these organisms were disregarded in the construction of Table 3. A. aneurinilyticus LMG 17161 was an outlier of the main Aneurinibacillus- $B$. badius group, although it behaved as a typical $A$. aneurinilyticus strain in other analyses. $A$. [aneurinilyticus] LMG 17164 was also recovered as an outlier, joining the Aneurinibacillus- $B$. badius group at $50 \% S_{G}$. This strain was received as $A$. aneurinilyticus but reclassified as a strain of $A$. migulanus by Shida et al. (20). It was found here to have a typical $A$. aneurinilyticus FAME profile. It might be an intermediate strain. One organism received as Brevibacillus brevis, LMG 15431, was recovered in the Brevibacillus agri cluster (Fig. 2) and may be identified as a member of the latter species.

In the dendrogram based on SDS-PAGE of cell proteins (Fig. 5), the $A$. aneurinilyticus and $A$. migulanus strains formed a heterogeneous cluster at $77 \%$ similarity. The division of this cluster into two subclusters was mainly caused by the number (one or two) of dense, high-molecular-weight bands in the $7.7 \times 10^{4}$ to $8.2 \times 10^{4}$ zone. Twelve of the $13 \mathrm{~B}$. aneurinolyticus strains investigated contained two such bands, which is consistent with the S-layer protein data reported by Shida et al. (20). Although $B$. badius LMG 12332 joined at the periphery of one of the subclusters, on visual inspection its protein profile showed greater resemblance to that of $B$. badius $\mathrm{LMG} 7122^{\mathrm{T}}$, except for a dense protein band with a molecular weight of $8.0 \times 10^{4}$ (Fig. 5). Indeed, by exclusion of the $7.7 \times 10^{4}$ to $8.2 \times 10^{4}$ molecular weight zone from numerical analysis (data not shown), the $A$. aneurinilyticus- $A$. migulanus cluster formed 
TABLE 3. Phenotypic characters that differentiate the studied strains of Aneurinibacillus species, Brevibacillus ${ }^{a}$ species, and B. badius

\begin{tabular}{|c|c|c|c|c|c|c|c|c|c|c|c|c|c|}
\hline Character $^{b}$ & $\begin{array}{c}A . \\
\text { aneurini- } \\
\text { lyticus }\end{array}$ & $\begin{array}{c}\text { A. } \\
\text { migula- } \\
\text { nus }\end{array}$ & $\begin{array}{c}\text { A. } \\
\text { thermoaero- } \\
\text { philus }\end{array}$ & $\begin{array}{c}B . \\
\text { badius }\end{array}$ & $\begin{array}{c}\text { Brevi- } \\
\text { bacillus } \\
\text { agri }\end{array}$ & $\begin{array}{c}\text { Brevi- } \\
\text { bacillus } \\
\text { brevis }\end{array}$ & $\begin{array}{c}\text { Brevi- } \\
\text { bacillus } \\
\text { formosus }\end{array}$ & $\begin{array}{c}\text { Brevi- } \\
\text { bacillus } \\
\text { parabrevis }\end{array}$ & $\begin{array}{c}\text { Brevi- } \\
\text { bacillus } \\
\text { latero- } \\
\text { sporus }\end{array}$ & $\begin{array}{c}\text { Brevi- } \\
\text { bacillus } \\
\text { borstel- } \\
\text { ensis }\end{array}$ & $\begin{array}{c}\text { Brevi- } \\
\text { bacillus } \\
\text { centro- } \\
\text { sporus }\end{array}$ & $\begin{array}{c}\text { Brevi- } \\
\text { bacillus } \\
\text { choshi- } \\
\text { nensis }\end{array}$ & $\begin{array}{l}\text { Brevi- } \\
\text { bacillus } \\
\text { reuszeri }\end{array}$ \\
\hline Parasporal bodies & - & - & - & - & $c_{-}$ & - & - & - & + & - & - & - & - \\
\hline \multicolumn{14}{|l|}{ Hydrolysis of: } \\
\hline Casein & - & - & + & + & + & + & + & + & + & + & - & - & - \\
\hline Gelatin & - & - & + & + & + & + & + & + & + & + & - & - & - \\
\hline \multicolumn{14}{|l|}{ Growth at: } \\
\hline $55^{\circ} \mathrm{C}$ & - & - & + & - & - & - & - & - & - & - & - & - & - \\
\hline $20^{\circ} \mathrm{C}$ & - & + & - & + & $\mathrm{v}^{c}$ & - & + & + & $\mathrm{v}$ & - & + & + & + \\
\hline \multicolumn{14}{|l|}{ Assimilation of: } \\
\hline 4-Aminobutyrate & - & + & $\mathrm{v}$ & + & - & $\mathrm{v}$ & $\mathrm{v}$ & - & - & - & - & - & + \\
\hline L-Aspartate & + & + & + & + & + & + & + & + & + & - & + & + & + \\
\hline Ethanolamine & + & + & + & - & + & $\mathrm{v}$ & + & + & $\mathrm{v}$ & + & - & $\mathrm{v}$ & - \\
\hline D-Fructose & - & + & $\mathrm{v}$ & - & + & + & + & - & + & + & - & - & $\mathrm{v}$ \\
\hline Fumarate & + & + & + & + & + & $\mathrm{v}$ & + & - & + & + & + & $\mathrm{v}$ & - \\
\hline D-Gluconate & $\mathrm{v}$ & + & - & - & + & + & + & + & - & + & + & - & + \\
\hline D-Glucosamine & - & - & - & - & - & + & - & $\mathrm{v}$ & - & - & + & - & - \\
\hline Glutarate & + & $\mathrm{v}$ & - & + & - & - & - & - & - & - & - & - & - \\
\hline DL-Glycerate & - & - & $\mathrm{v}$ & - & - & - & - & - & + & + & - & - & + \\
\hline Glycerol & + & + & + & + & + & + & + & + & + & + & - & - & - \\
\hline 2-Ketoglutarate & $\mathrm{v}$ & $\mathrm{v}$ & + & + & + & $\mathrm{v}$ & + & + & $\mathrm{v}$ & - & + & - & + \\
\hline DL-Lactate & + & + & + & + & + & - & + & - & - & - & + & - & + \\
\hline Lactulose & - & - & - & - & - & - & - & - & - & - & - & - & + \\
\hline D-Malate & $\mathrm{v}$ & - & + & - & - & - & - & - & - & - & - & - & - \\
\hline Maltose & - & - & - & - & + & + & + & + & + & - & - & - & - \\
\hline $\mathrm{N}$-Acetyl-D-glucosamine & - & - & + & - & + & + & + & + & + & - & + & + & + \\
\hline Putrescine & + & + & + & + & + & - & - & + & - & - & $\mathrm{v}$ & $\mathrm{v}$ & + \\
\hline Quinate & - & - & + & - & - & - & - & - & - & - & - & - & - \\
\hline L-Sorbose & - & - & + & - & - & - & - & - & - & - & - & - & - \\
\hline Sucrose & $\mathrm{v}$ & - & - & + & + & + & + & + & - & - & - & - & - \\
\hline L-Tartrate & - & - & + & - & - & - & - & - & - & - & - & - & - \\
\hline D-Trehalose & $\mathrm{v}$ & - & - & - & + & + & + & + & + & - & - & - & - \\
\hline Tricarballylate & - & - & + & - & - & - & - & - & - & - & - & - & - \\
\hline D-Turanose & - & - & $\mathrm{v}$ & - & + & + & + & + & - & - & - & - & - \\
\hline L-Tyrosine & - & + & + & - & $\mathrm{v}$ & - & - & $\mathrm{v}$ & - & - & - & - & - \\
\hline
\end{tabular}

${ }^{a}$ One strain of Brevibacillus thermoniber could be distinguished from thc other species by its production of a red-orange pigment, positive results for hydrolysis of casein and gelatin, growth at $55^{\circ} \mathrm{C}$, and negative results for all the other characters listed.

${ }^{b}$ With the exceptions of spore morphology, hydrolysis of casein and gelatin, and growth at 55 and $20^{\circ} \mathrm{C}$, all characters were determined by tests in the API Biotype 100 system.

${ }^{c} \mathrm{v}$, Between-strain variation.

at $88 \%$ similarity, with the $A$. migulanus type strain linking at $81 \%$ similarity, and was quite distinct ( $76 \%$ similarity) from the two tightly ( $93 \%$ similarity) clustered $B$. badius strains. The SDS-PAGE profiles of the $A$. aneurinilyticus and $A$. migulanus strains clearly differed from those of the Brevibacillus species (Fig. 5). The SDS-PAGE profiles of the two B. thermoaerophilus strains, grown either at 30 or $55^{\circ} \mathrm{C}$, showed little resemblance to each other or to those of the other species examined and were characterized by a dense band of variable high molecular weight (Fig. 5), probably corresponding to the glycosylated S-layer proteins described previously (16).

An initial Py-MS analysis showed that the Aneurinibacillus strains were very closely related to, but nevertheless distinct from, strains of the Brevibacillus species examined. Removal of a number of outlying strains of $B$. badius and $B$. laterosporus, which alleviates the compression of other groups that is known to be caused by outliers (24), led to the results presented in Fig. 3. The genus Aneurinibacillus is distinct from the genus Brevibacillus and from $B$. badius, but Py-MS analysis does not allow separation of $A$. aneurinilyticus and $A$. migulanus. Similarly, the two-dimensional canonical variates analysis plot of the data (Fig. 4) indicates that these two species overlap each other but are separate from the other organisms examined.

Since our polyphasic data showed a very close relationship between $A$. aneurinilyticus and $A$. migulanus, and SDS-PAGE of whole-cell proteins and Py-MS (two techniques known to delineate taxa at the species and subspecies levels [24 and 28]) did not enable a reliable separation of the two species, we reexamined the DNA-DNA homology between the respective type strains. This was also prompted by the contradictory DNA homology values (ranging from 0 to $38 \%$ ) for the type strains reported in the literature $(20,27)$. In our study, a DNA homology value of $40.5 \% \pm 1.5 \%$ (mean \pm standard deviation of two determinations) was measured, which confirms one of the previously reported data (27) and also confirms the validity of $A$. aneurinilyticus and $A$. migulanus as separate but highly related species. Nevertheless, this indicates the importance of the DNA-DNA hybridization method used for achieving taxonomic conclusions.

Conclusion. Members of the genus Aneurinibacillus (B. thermoaerophilus included) can be distinguished phylogenetically (by ARDRA and complete $16 \mathrm{~S}$ rDNA sequence comparison 


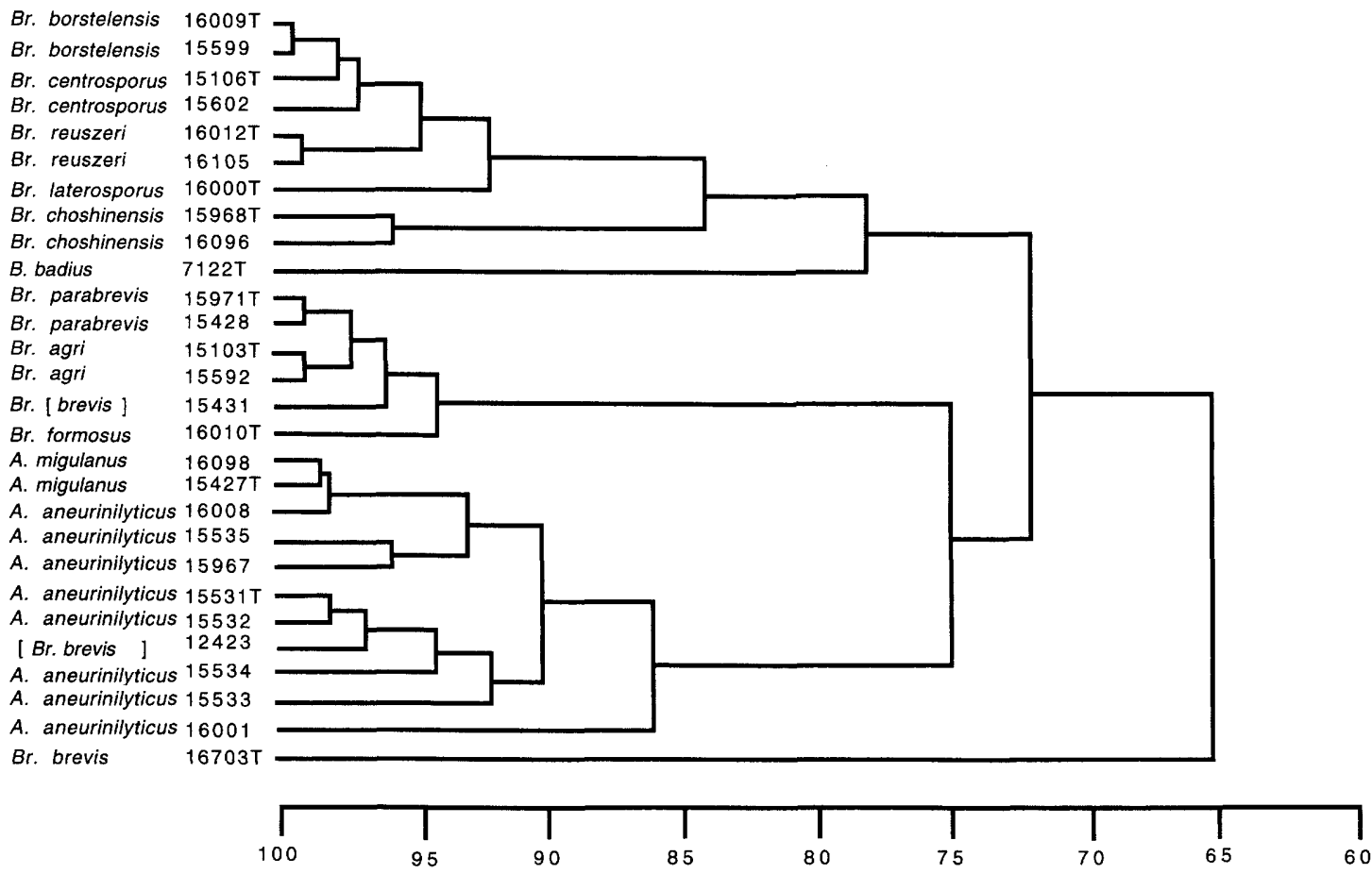

FIG. 3. Dendrogram based on the UPGMA clustering of similarity coefficients $\left(S_{G}\right)$ of Py-MS data from 8 A. aneurinilyticus and 2 A. migulanus strains, 1 B. badius strain, and 17 representatives of the genus Brevibacillus $(B r$.$) T's indicate the positions of type strains. Misidentified strains are shown in brackets.$

[this paper and, e.g., references 16 and 23) from Brevibacillus species. Although only a relatively small number of phenotypic characters separate the genus Aneurinibacillus from the genus Brevibacillus and from B. badius (a member of Bacillus rRNA group 1), a phenotypic differentiation is possible. These arguments favor the reclassification of $B$. thermoaerophilus as Aneurinibacillus thermoaerophilus comb. nov. Emended descriptions of the genus Aneurinibacillus and its three species, $A$. aneurinilyticus, $A$. migulanus, and $A$. thermoaerophilus, follow.

Emended description of the genus Aneurinibacillus. Aneurinibacillus (A.neu.ri.ni.ba.cil'lus. M. L. n. aneurinum, thiamine; L. dim. n. bacillus, small rod, Bacillus, a genus of endospore-forming rods; M. L. masc. Aneurinibacillus, a genus of thiamine-decomposing, endospore-forming rods). The descriptions below are based on our own observations and previous descriptions of the species belonging to this genus $(16,20,27)$. Although the two species Aneurinibacillus aneurinilyticus and Aneurinibacillus migulanus are retained, it should be noted that these two species are difficult to distinguish by routine tests.

Gram-positive, rod-shaped cells, 0.5 to $1.0 \mu \mathrm{m}$ by 2.0 to 6.0 $\mu \mathrm{m}$, and motile by peritrichous flagella. Ellipsoidal spores, one per cell, are borne centrally, paracentrally, and subterminally and swell the sporangia slightly or not at all. Strictly aerobic. Growth on routine media such as nutrient agar and Trypticase soy agar. Decompose thiamine. Catalase positive, weakly positive, or negative. Nitrate reduction variable. Casein, gelatin, and Tween 80 hydrolysis variable. Starch and urea are not hydrolyzed; indole is not produced. Growth temperatures range from 20 to $60^{\circ} \mathrm{C}$. Growth at $\mathrm{pH} 5.5$ to 9.0 . Growth occurs in the presence of $2 \% \mathrm{NaCl}$ but not $5 \% \mathrm{NaCl}$. Few carbohydrates are assimilated, and acid is produced weakly if at all from them; amino acids and some organic acids are used as carbon sources. The following carbon sources are assimilated in the API Biotype 100 system: D-alanine, 5-aminovalerate, L-aspartate, ethanolamine, fumarate, L-glutamate, glycerol, 3-hydroxybutyrate, DL-lactate, L-proline, and putrescine. The major cellular fatty acid components (ranges [percent of total] are given in parentheses) are $15: 0$ iso (41.9 to $66.8 \%$ ), $16: 0$ iso (0.5 to $6.6 \%), 16: 0(1.8$ to $8.5 \%)$, and $17: 0$ iso $(1.0$ to $23.8 \%)$.

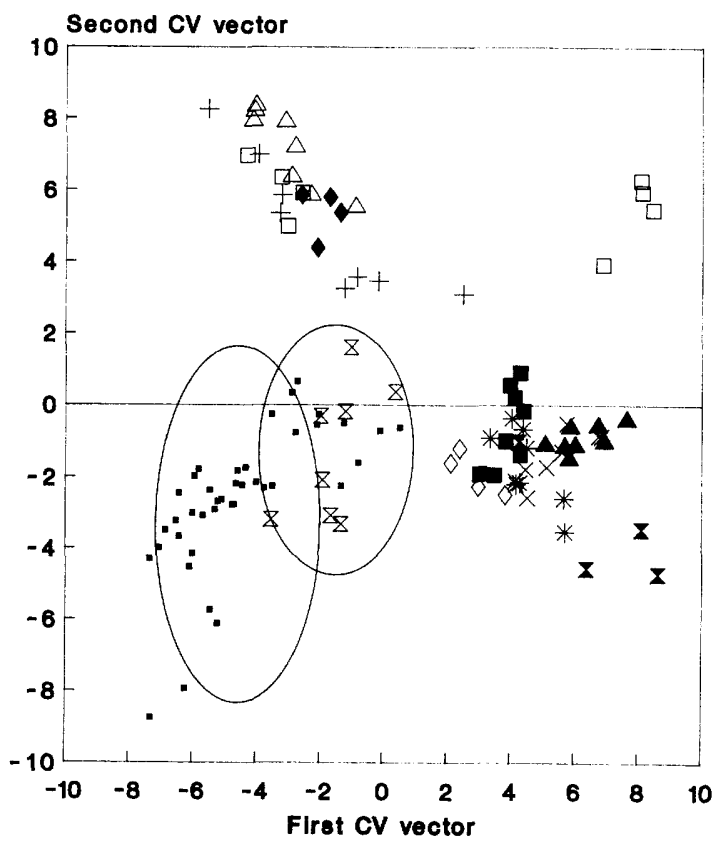

FIG. 4. A canonical variates (CV) analysis plot of Py-MS data for strains of A. aneurinilyticus ( $),$ A. migulanus $(\bar{\nabla})$, Brevibacillus agri $(+), B$. badius $(\mathbf{X})$ Brevibacillus brevis $(\square)$, Brevibacillus borstelensis $(\times)$, Brevibacillus centrosporus $(*)$, Brevibacillus choshinensis $(\square)$, Brevibacillus laterosporus $(\diamond)$, Brevibacillus parabrevis $(\triangle)$, Brevibacillus formosus $(\bullet)$, and Brevibacillus reuszeri $(\mathbf{\Delta})$. 


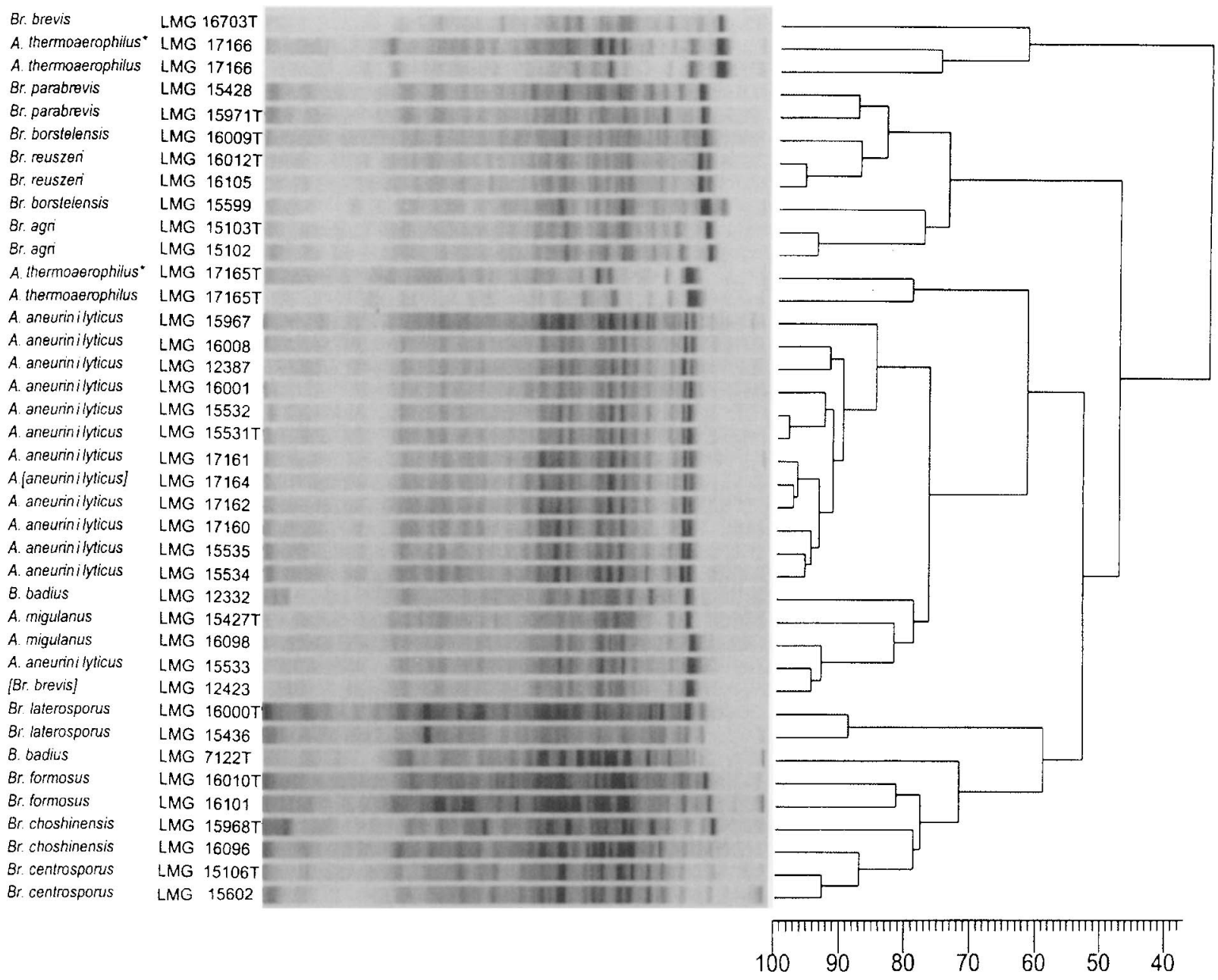

FIG. 5. Normalized computer profiles of SDS-PAGE analysis of whole-cell proteins of 13 A. aneurinilyticus strains, 3 A. migulanus strains, 2 A. thermoaerophilus strains, $2 \mathrm{~B}$. badius strains, and 18 representatives of the genus Brevibacillus $(B r)$. The dendrogram was based on the UPGMA clustering of the correlations $(r)$ of the total-protein profiles. T's indicate the positions of type strains. Misidentified strains are shown in brackets. Asterisks indicate that the cells were grown at $30^{\circ} \mathrm{C}$.

The major quinone is menaquinone 7. A specific S-layer protein is present. The $\mathrm{G}+\mathrm{C}$ content ranges from 42 to $47 \mathrm{~mol} \%$.

The type species is Aneurinibacillus aneurinilyticus, represented by type strain LMG $15531^{\mathrm{T}}\left(=\right.$ ATCC $12856^{\mathrm{T}}=\mathrm{B} 0205^{\mathrm{T}}=$ NRRL NRS-1589 $)$.

Emended description of Aneurinibacillus aneurinilyticus corrig. Aneurinibacillus aneurinilyticus (an.eur.in.i.ly'tic.us. M. L. n. aneurinum, thiamine; M. L. adj. lyticus, dissolving; M. L. adj. aneurinilyticus, decomposing thiamine). The following characters are in addition to those given above for the genus. Colonies on nutrient agar after $48 \mathrm{~h}$ at $37^{\circ} \mathrm{C}$ are flat, 0.5 to $2 \mathrm{~mm}$ in diameter, round or irregular in shape, with slightly crenate edges, and they are glossy, translucent, and creamy greyish. Colonies become whitish and opaque as their component cells sporulate. Vegetative cells are 0.7 to $0.9 \mu \mathrm{m}$ by 3.0 to $5.0 \mu \mathrm{m}$. Weakly catalase positive. Growth temperatures range from 25 to $50^{\circ} \mathrm{C}$. Growth at $\mathrm{pH} 5.0$ to 9.0 . Optimum temperature for growth, $37^{\circ} \mathrm{C}$; optimum $\mathrm{pH}$ for growth, 7.0. Nitrate is reduced to nitrite. Casein, gelatin, and Tweens $20,40,60$, and 80 are not hydrolyzed.

The following carbon source, in addition to those listed in the genus description above, is assimilated in the API Biotype 100 system: glutarate. Assimilation of $N$-acetyl-D-glucosamine, adonitol, L-alanine, D-cellobiose, D-gluconate, 2-ketoglutarate, $\alpha$-lactose, D- and L-malate, $\alpha$-D-melibiose, $1-O-$-methyl- $\beta$-D-glucopyranoside, phenylacetate, propionate, D-ribose, L-serine, succinate, sucrose, D-tartrate, and D-trehalose varies among strains. The following carbon sources are not assimilated: cisand trans-aconitate, esculin, 4-aminobutyrate, L-arabinose, Dand L-arabitol, benzoate, betain, caprate, caprylate, citrate, $m$-coumarate, dulcitol, $i$-erythritol, $\beta$-D-fructose, $\alpha$-L-fucose, $\mathrm{D}$ galactose, $\mathrm{D}$-galacturonate, $\beta$-gentiobiose, gentisate, $\mathrm{D}$-glucose, D-glucosamine, D-glucuronate, DL-glycerate, histamine, L-histidine, 3-hydroxybenzoate, 4-hydroxybenzoate, hydroxyquinoline- $\beta$-glucuronide, $m y o$-inositol, itaconate, 2 -keto-D-gluconate, 5-keto-D-gluconate, lactulose, D-lyxose, malonate, maltitol, maltose, maltotriose, D-mannitol, D-mannose, D-melezitose, 1-O-methyl- $\alpha$-galactopyranoside, 1-O-methyl- $\beta$-galactopyranoside, 1-O-methyl- $\alpha$-D-glucopyranoside, 3-O-methyl-D-glucopyranose, mucate, palatinose, 3-phenylpropionate, protocatechuate, quinate, D-raffinose, $\alpha$-L-rhamnose, D-saccharate, D-sorbitol, Lsorbose, D-tagatose, L-tartrate, meso-tartrate, tricarballylate, trigonelline, tryptamine, L-tryptophan, D-turanose, L-tyrosine, xylitol, and D-xylose. The major cellular fatty acid components (ranges [percent of total] are given in parentheses) are 14:0 iso (1.4 to $8.8 \%) ; 14: 0$ (1.6 to $4.0 \%) ; 15: 0$ iso (41.9 to $66.3 \%) ; 16: 0$ iso $(0.5$ to $4.2 \%) ; 16: 1 \omega 11 \mathrm{c}(8.0$ to 13.5$) ; 16: 0$ (2.2 to $8.5 \%)$; iso $17: 1 \omega 10 \mathrm{c}(1.5$ to $3.4 \%) ; 17: 0$ iso $(1.0$ to $3.4 \%) ; 15: 1$ iso $\mathrm{H}$ 
and/or $15: 1$ iso I, and/or $13: 03-\mathrm{OH}(0.9$ to $2.8 \%) ; 16: 1 \omega 7 \mathrm{c}$ and/or 15:0 iso $2-\mathrm{OH}$ (2.7 to $10.3 \%)$; and $17: 1$ iso $\mathrm{I}$ and/or $17: 1$ anteiso $\mathrm{B}(1.0$ to $3.5 \%)$. The $\mathrm{G}+\mathrm{C}$ content ranges from 41.1 to $43.4 \mathrm{~mol} \%$ (as determined by high-performance liquid chromatography [HPLC] [20]).

The type strain is LMG $15531^{\mathrm{T}}$ (= ATCC $12856^{\mathrm{T}}=$ $\mathrm{B} 0205^{\mathrm{T}}=\mathrm{NRRL}$ NRS $-1589^{\mathrm{T}}$ ), and this strain has the characteristics of the species described above. It has a $\mathrm{G}+\mathrm{C}$ content of $42.9 \mathrm{~mol} \%$. This strain assimilates 2 -ketoglutarate, L-malate, phenylacetate, propionate, D-ribose, L-serine, and succinate.

Emended description of Aneurinibacillus migulanus. Aneurinibacillus migulanus (mi.gu.la'nus. M. L. adj. migulanus, referring to the German bacteriologist W. Migula, who contributed to bacterial taxonomy). The following characters are in addition to those given above for the genus. Colonies on nutrient agar after $48 \mathrm{~h}$ at $37^{\circ} \mathrm{C}$ are flat, 2 to $3 \mathrm{~mm}$ in diameter, with crenate edges, and they are translucent, yellowish grey, and glossy. Colonies become creamy white and opaque as their component cells sporulate. Vegetative cells are 0.5 to $1.0 \mu \mathrm{m}$ by 2.0 to $6.0 \mu \mathrm{m}$. Catalase positive. Growth temperatures range from 20 to $50^{\circ} \mathrm{C}$. Growth at pH 5.5 to 9.0 . Nitrate is reduced to nitrite. Casein, gelatin, and Tweens 20, 40, 60, and 80 are not hydrolyzed. The following carbon sources, in addition to those listed in the genus description above, are assimilated in the API Biotype 100 system: L-alanine, 4-aminobutyrate, $\beta$-D-fructose, D-gluconate, phenylacetate, propionate, D-ribose, L-serine, succinate, and L-tyrosine. Assimilation of cis- and transaconitate, glutarate, myo-inositol, 2-ketoglutarate, and L-malate varies among strains. The following carbon sources are not assimilated: $N$-acetyl-D-glucosamine, adonitol, esculin, L-arabinose, D- and L-arabitol, benzoate, betain, caprate, caprylate, D-cellobiose, citrate, $m$-coumarate, dulcitol, $i$-erythritol, $\alpha$-L-fucose, D-galactose, D-galacturonate, $\beta$-gentiobiose, gentisate, D-glucose, D-glucosamine, D-glucuronate, DL-glycerate, histamine, L-histidine, 3-hydroxybenzoate, 4-hydroxybenzoate, hydroxyquinoline- $\beta$-glucuronide, itaconate, 2-keto-D-gluconate, 5-keto-Dgluconate, $\alpha$-lactose, lactulose, D-lyxose, D-malate, malonate, maltitol, maltose, maltotriose, D-mannitol, D-mannose, $\alpha$-Dmelibiose, D-melezitose, 1-O-methyl- $\alpha$-galactopyranoside, 1-Omethyl- $\beta$-galactopyranoside, $1-O-$-methyl- $\beta$-D-glucopyranoside, 1-O-methyl- $\alpha$-D-glucopyranoside, 3-O-methyl-D-glucopyranose, mucate, palatinose, 3-phenylpropionate, protocatechuate, quinate, D-raffinose, $\alpha$-L-rhamnose, D-saccharate, D-sorbitol, L-sorbose, sucrose, D-tagatose, D- and L-tartrate, meso-tartrate, D-trehalose, tricarballylate, trigonelline, tryptamine, L-tryptophan, Dturanose, xylitol, and D-xylose. The major cellular fatty acid components (ranges [percent of total] are given in parentheses) are $14: 0$ iso (8.3 to $9.6 \%) ; 14: 0$ (1.8 to $2.0 \%) ; 15: 0$ iso (48.3 to $48.9 \%) ; 15: 0$ anteiso $(1.3 \%) ; 15: 1 \omega 6 \mathrm{c}(0.8$ to $1.0 \%) ; 15: 0$ (2.3 to $3.3 \%)$; $16: 1 \omega 7 \mathrm{c}$ alcohol $(1.4 \%)$; $16: 1$ iso $\mathrm{H}(1.3$ to $1.7 \%) ; 16: 0$ iso $(6.5$ to $6.6 \%) ; 16: 1 \omega 11 \mathrm{c}(6.4$ to $6.6 \%) ; 16: 1 \omega 5 \mathrm{c}$ (1.1 to $1.2 \%)$; $16: 0$ (3.4 to $3.6 \%$ ); iso $17: 1 \omega 10 \mathrm{c}(1.7$ to $2.2 \%)$; $17: 0$ iso $(2.1 \%)$; $17: 1 \omega 6 \mathrm{c}(1.4$ to $1.7 \%) ; 15: 1$ iso $\mathrm{H}$ and/or $15: 1$ iso I, and/or 13:0 3-OH (1.3 to $1.6 \%) ; 16: 1 \omega 7 \mathrm{c}$ and/or $15: 0$ iso $2-\mathrm{OH}$ (4.8 to $5.0 \%)$; and $17: 1$ iso I and/or $17: 1$ anteiso B (2.4 to $2.5 \%$ ). The $\mathrm{G}+\mathrm{C}$ content ranges from 42.5 to $43.2 \mathrm{~mol} \%$ (as determined by HPLC [27]).

The type strain is LMG $15427^{\mathrm{T}}\left(=\right.$ ATCC $9999^{\mathrm{T}}=\mathrm{B} 0270^{\mathrm{T}}$ $=$ NCTC $7096^{\mathrm{T}}$ ), and this strain has the characteristics of the species described above. It has a $\mathrm{G}+\mathrm{C}$ content of $42.5 \mathrm{~mol} \%$. This strain assimilates glutarate, myo-inositol, 2-ketoglutarate, and L-malate.

Emended description of Aneurinibacillus thermoaerophilus comb. nov. The following characters are in addition to those given above for the genus or are those in which members of this species differ from the characters given for the genus.

Colonies on nutrient agar after $24 \mathrm{~h}$ at $55^{\circ} \mathrm{C}$ are flat, 1 to 10 $\mathrm{mm}$ in diameter, irregular in shape, with a tendency to swarm across the surface of the agar, and they are matte, translucent, and creamy greyish in appearance, becoming whitish and opaque in their centers. Vegetative cells are 1.0 to $1.2 \mu \mathrm{m}$ by 3.5 to $5.5 \mu \mathrm{m}$. Catalase production is variable. Growth temperatures range from 40 to $60^{\circ} \mathrm{C}$, and growth occurs from $\mathrm{pH}$ 7.0 to 8.0. Hydrolyzes casein, gelatin, and Tween 80 , and produces acid from glucose and glycerol. Nitrate is not reduced. The following carbon sources, in addition to those listed in the genus description above, are assimilated in the API Biotype 100 system: $N$-acetyl-D-glucosamine, esculin, L-alanine, 2-ketoglutarate, D- and L-malate, phenylacetate, propionate, quinate, D-ribose, L-sorbose, succinate, L-tartrate, meso-tartrate, tricarballylate, and L-tyrosine. Assimilation of trans-aconitate, 4-aminobutyrate, D-arabitol, citrate, $\beta$-D-fructose, D-galacturonate, $\alpha$-D-glucose, DL-glycerate, histamine, D-lyxose, D-mannitol, $\alpha$-D-melibiose, 3-O-methyl-D-glucopyranose, 3-phenylpropionate, L-serine, D-tartrate, trigonelline, D-turanose, and $D$-xylose varies among strains. The following carbon sources are not assimilated: cis-aconitate, adonitol, L-arabinose, L-arabitol, benzoate, betain, caproate, caprylate, D-cellobiose, $m$ coumarate, dulcitol, $i$-erythritol, $\alpha$-L-fucose, D-galactose, $\beta$-gentiobiose, gentisate, D-gluconate, D-glucosamine, D-glucuronate, glutarate, L-histidine, 3-hydroxybenzoate, 4-hydroxybenzoate, hydroxyquinoline- $\beta$-glucuronide, myo-inositol, itaconate, 2-keto-D-gluconate, 5-keto-D-gluconate, $\alpha$-lactose, lactulose, malonate, maltitol, maltose, maltotriose, D-mannose, D-melezitose, 1-O-methyl- $\alpha$-galactopyranoside, $\quad 1-O-m e t h y l-\beta$-galactopyranoside, 1-O-methyl- $\beta$-D-glucopyranoside, 1 -O-methyl- $\alpha$-D-glucopyranoside, mucate, palatinose, protocatechuate, D-raffinose, $\alpha-\mathrm{L}$ rhamnose, D-saccharate, D-sorbitol, sucrose, D-tagatose, D-trehalose, tryptamine, L-tryptophan, and xylitol. The major cellular fatty acid components (ranges [percent of total] are given in parentheses) are 15:0 iso (50.3 to 66.8\%), 15:0 anteiso (10.3\%; may be absent), $15: 0$ (0.9 to $3.4 \%), 16: 0$ iso (3.5 to $4.1 \%), 16: 0$ (1.8 to $2.5 \%), 17: 0$ iso $(23.4$ to $23.8 \%$ ), and $17: 0$ anteiso ( $8.3 \%$; may be absent). The $\mathrm{G}+\mathrm{C}$ content ranges from 46.3 to $46.7 \mathrm{~mol} \%$ (as determined by HPLC [16]).

The type strain is LMG $17165^{\mathrm{T}}$ (= DSM $10154^{\mathrm{T}}$ ), and this strain has the characteristics of the species described above. It has a $\mathrm{G}+\mathrm{C}$ content of $46.7 \mathrm{~mol} \%$ and assimilates D-arabitol, D-galacturonate, $\alpha$-D-glucose, DL-glycerate, histamine, D-lyxose, D-mannitol, 3-0-methyl-D-glucopyranose, D-tartrate, D-turanose, and Dxylose.

\section{ACKNOWLEDGMENTS}

We are most grateful to bioMérieux SA (Marcy l'Etoile, France) for the gifts of API Biotype 100 strips and Biotype Suspension Medium and for supporting G.F. We express our gratitude to L. K. Nakamura for providing cultures. P.D.V. and M.H. are indebted to the Fund for Scientific Research (Belgium) for positions as Senior Research Associate and Postdoctoral Research Fellow, respectively, and N.A. is grateful for funding from the University of Kuwait. R.C.W.B., M.H., N.A.L., and P.D.V. are most grateful to the British Council and the Fund for Scientific Research (Belgium) for a travel grant. K.K. acknowledges the Fund for Medical Scientific Research (Belgium) for personnel and research grants. P.D.V. acknowledges the "Onderzoeksfonds" van de RUG for research and personnel grants.

\section{REFERENCES}

1. Aoyama, S. 1952. Studies on the thiamin decomposing bacterium. I. Bacteriological researches of a new thiamin decomposing Bacillus, Bacillus aneurinolyticus Kimura et Aoyama. Acta Med. Univ. Kyoto 30:127-132.

2. Ash, C., J. A. E. Farrow, S. Wallbanks, and M. D. Collins. 1991. Phylogenetic 
heterogeneity of the genus Bacillus revealed by comparative analysis of small-subunit-ribosomal RNA sequences. Lett. Appl. Microbiol. 13:202-206.

3. Claus, D., and R. C. W. Berkeley. 1986. Genus Bacillus Cohn 1872, p. 1105-1139. In P. H. A. Sneath, N. S. Mair, M. E. Sharpe, and J. G. Holt (ed.), Bergey's manual of systematic bacteriology, vol. 2. The Williams \& Wilkins Co., Baltimore, $\mathrm{Md}$.

4. De Ley, J., H. Cattoir, and A. Reynaerts. 1970. The quantitative measurement of DNA hybridization from renaturation rates. Eur. J. Biochem. 12: $133-142$

5. Farrow, J. A. E., C. Ash, S. Wallbanks, and M. D. Collins. 1992. Phylogenetic analysis of the genera Planococcus, Marinococcus and Sporosarcina and their relationships to members of the genus Bacillus. FEMS Microbiol. Lett. 93:167-172

6. Farrow, J. A. E., S. Wallbanks, and M. D. Collins. 1994. Phylogenetic interrelationships of round-spore-forming bacilli containing cell walls based on lysine and the non-spore-forming genera Caryophanon, Exiguobacterium, Kurthia, and Planococcus. Int. J. Syst. Bacteriol. 44:74-82.

7. Goodacre, R., and R. C. W. Berkeley. 1990. Detection of small genotypic changes in Escherichia coli by pyrolysis mass spectrometry. FEMS Microbiol. Lett. 71:133-138.

8. Gordon, R. E., W. C. Haynes, and C. H.-N. Pang. 1973. The genus Bacillus. Agriculture handbook no. 427. U. S. Department of Agriculture, Washington, D.C

9. Gower, J. C. 1971. A general coefficient of similarity and some of its properties. Biometrics 27:857-874.

10. Heyndrickx, M., K. Vandemeulebroecke, P. Scheldeman, B. Hoste, K. Kersters, P. De Vos, N. A. Logan, A. M. Aziz, N. Ali, and R. C. W. Berkeley. 1995. Paenibacillus (formerly Bacillus) gordonae (Pichinoty et al. 1986) Ash et al 1994 is a later subjective synonym of Paenibacillus (formerly Bacillus) validus (Nakamura 1984) Ash et al. 1994: emended description of $P$. validus. Int. J. Syst. Bacteriol. 45:661-669.

11. Heyndrickx, M., L. Vauterin, P. Vandamme, K. Kersters, and P. De Vos. 1996. Applicability of combined amplified 16S rDNA restriction analysis (ARDRA) patterns in bacterial phylogeny and taxonomy. J. Microbiol. Methods 26:247-259.

12. Heyndrickx, M., K. Vandemeulebroecke, P. Scheldeman, K. Kersters, P. De Vos, N. A. Logan, A. M. Aziz, N. Ali, and R. C. W. Berkeley. 1996. A polyphasic reassessment of the genus Paenibacillus, reclassification of Bacillus lautus (Nakamura 1984) as Paenibacillus lautus comb. nov and of Bacillus peoriae (Montefusco et al. 1993) as Paenibacillus peoriae comb. nov., and emended descriptions of $P$. lautus and of $P$. peoriae. Int. J. Syst. Bacteriol. 46:988-1003.

13. International Committee on Systematic Bacteriology Subcommittee on the Taxonomy of the Genus Bacillus. 1993. Minutes of the meeting, 15 April 1992, Badock Hall, Bristol, United Kingdom. Int. J. Syst. Bacteriol. 43:185.

14. Logan, N. A. 1994. Bacterial systematics. Blackwell Scientific Publications, Oxford, United Kingdom.

15. Logan, N. A., and R. C. W. Berkeley. 1984. Identification of Bacillus strains using the API system. J. Gen. Microbiol. 130:1871-1882

16. Meier-Stauffer, K., H.-J. Busse, F. A. Rainey, J. Burghardt, A. Scheberl, F. Hollaus, B. Kuen, A. Makristathis, U. B. Sleytr, and P. Messner. 1996 Description of Bacillus thermoaerophilus sp. nov., to include sugar beet isolates and Bacillus brevis ATCC 12990. Int. J. Syst. Bacteriol. 46:532-541.

17. Nakamura, L. K. 1993. DNA relatedness of Bacillus brevis Migula 1900 strains and proposal of Bacillus agri sp. nov., nom. rev., and Bacillus centro sporus sp. nov., nom. rev. Int. J. Syst. Bacteriol. 43:20-25.

18. Pitcher, D. G., N. A. Saunders, and R. J. Owen. 1989. Rapid extraction of bacterial genomic DNA with guanidium thiocyanate. Lett. Appl. Microbiol. 8:151-156.

19. Pot, B., P. Vandamme, and K. Kersters. 1994. Analysis of electrophoretic whole organism protein fingerprints, p. 493-521. In M. Goodfellow and A. G. O'Donnell (ed.), Chemical methods in prokaryotic systematics. John Wiley \& Sons, Chichester, United Kingdom.

20. Shida, O., H. Takagi, K. Kadowaki, H. Yano, M. Abe, S. Udaka, and K Komagata. 1994. Bacillus aneurinolyticus sp. nov., nom. rev. Int. J. Syst. Bacteriol. 44:143-150.

21. Shida, O., H. Takagi, K. Kadowaki, S. Udaka, and K. Komagata. 1994 Bacillus galactophilus is a later subjective synonym of Bacillus agri. Int. J. Syst Bacteriol. 44:172-173.

22. Shida, O., H. Takagi, K. Kadowaki, S. Udaka, L. K. Nakamura, and K. Komagata. 1995. Proposal of Bacillus reuszeri sp. nov., Bacillus formosus $\mathrm{sp}$ nov., nom. rev., and Bacillus borstelensis sp. nov., nom. rev. Int. J. Syst. Bacteriol. 45:93-100.

23. Shida, O., H. Takagi, K. Kadowaki, and K. Komagata. 1996. Proposal for two new genera, Brevibacillus gen. nov. and Aneurinibacillus gen. nov. Int. J. Syst. Bacteriol. 46:939-946.

24. Shute, L. A., C. S. Gutteridge, J. R. Norris, and R. C. W. Berkeley. 1984 Curie-point pyrolysis mass spectrometry applied to the characterization and identification of selected Bacillus species. J. Gen. Microbiol. 130:343-355.

25. Skerman, V. B. D., V. McGowan, and P. H. A. Sneath. 1980. Approved lists of bacterial names. Int. J. Syst. Bacteriol. 30:225-420.

26. Suzuki, K., M. Goodfellow, and A. G. O'Donnell. 1993. Cell envelopes and classification, p. 195-238. In M. Goodfellow and A. G. O'Donnell (ed.) Handbook of new bacterial systematics. Academic Press, London, United Kingdom.

27. Takagi, H., O. Shida, K. Kadowaki, K. Komagata, and S. Udaka. 1993. Characterization of Bacillus brevis with descriptions of Bacillus migulanus sp. nov., Bacillus choshinensis sp. nov., Bacillus parabrevis sp. nov., and Bacillus galactophilus sp. nov. Int. J. Syst. Bacteriol. 43:221-231.

28. Vandamme, P., B. Pot, M. Gillis, P. De Vos, K. Kersters, and J. Swings. 1996 Polyphasic taxonomy, a consensus approach to bacterial systematics. Microbiol. Rev. 60:407-438.

29. Vauterin, L., P. Yang, B. Hoste, M. Vancanneyt, E. L. Civerolo, J. Swings, and K. Kersters. 1991. Differentiation of Xanthomonas campestris pv. citri strains by sodium dodecyl sulfate-polyacrylamide gel electrophoresis of proteins, fatty acid analysis, and DNA-DNA hybridization. Int. J. Syst. Bacteriol. 41:535-542.

30. Vauterin, L., and P. Vauterin. 1992. Computer aided objective comparison of electrophoretic patterns for grouping and identification of microorganisms. Eur. Microbiol. 1:37-41.

31. Willems, A., J. Busse, M. Goor, B. Pot, E. Falsen, E. Jantzen, B. Hoste, M. Gillis, K. Kersters, G. Auling, and J. De Ley. 1989. Hydrogenophaga, a new genus of hydrogen-oxidizing bacteria that includes Hydrogenophaga flave comb. nov. (formerly Pseudomonas flava), Hydrogenophaga palleronii (formerly Pseudomonas palleronii), Hydrogenophaga pseudofiava (formerly Pseudomonas pseudoflava and "Pseudomonas carboxydoflava"), and Hydrogenophaga taeniospiralis (formerly Pseudomonas taeniospiralis). Int. J. Syst. Bacteriol. 39:319-333. 